\title{
EXTRACT THE AROMATIC OIL OF THE ROSEMARY PLANT BY STEAM DISTILLATION AND HYDRO-DISTILLATION METHODS
}

\author{
Arafa. G. K.*
}

\section{ABSTRACT}

Pure essential oils are extracted from various parts of plants and are widely used in various fields of industries, such as perfumery and pharmaceutical industries. These essential oils have a high commercial value because of their therapeutic properties. The objective of this study is to study the behavior of rosemary oil extraction by using both steam distillation and hydro distillation method including quantity, components and ratios of distilled oil analysis and oil analysis. Gas chromatography for the effect of extraction time (5, 10, 15, 30, 60, 90 and $120 \mathrm{~min}$ ) on yield and composition of essential oil obtained by water distillation method and steam distillation method at three different levels of water vapor flow (3 l / min, $6 \mathrm{l} / \mathrm{min}$ and $9 \mathrm{l} / \mathrm{min}$ ) was also investigted. This research revealed different behaviors of the main components of rosemary oil. $\alpha$-pinene and 1.8-cineole and camphor in the treatment with the amount of vapor flow rate. Experience has shown that steam distillation method is better than water distillation based on the ratio of oil and its components.

\section{INTRODUCTION}

$\mathrm{E}$ ssential oils of plants have many applications in medicines, cosmetics, food stuff and pharmaceutical industries. They are present in plants at low concentration which would require high performance extraction techniques in order to achieve high yield. Generally, essential oils are produced by different methods, including solvent extraction, supercritical fluid extraction, hydro-distillation, steam distillation, use of superheated steam and combinations of the previous techniques with others such as ultrasound and microwave-assisted processes (Chemat et al. 2006 and Masango 2005). Rajeswara (2002) showed that the steam distillation is one of the most popular methods because of its low cost in comparison with advanced methods such as supercritical fluid extraction and its green approach compared to solvent extraction.

\footnotetext{
*Ag. Eng. Res. Institute., Ag. Res. Center
} 
This method has been actively pursued since the beginning of the 1980s. In the literature there are some studies of oil extraction by steam distillation.Masango (2005). studied the effects of increasing the steam flow rate and steam jacket as well as appropriate insulation of distillation column in extracting essential oil from Artemisia and Lavender plants by steam distillation, optimizing the consumption of energy and increasing the final yield of extraction. Romdhane et al. and Tizaoui ( 2005) presented a mathematical model for optimizing the steam distillation process for preparation of Pimpinella anisum oil. Chemat et al. (2006) Using a microwave heater instead of an electric ovn decreased the time of extraction and improved the quality of Artemisia oil. In another study the effect of crushing of the plant and time of extraction on the yield and chemical composition of Coriander oil was reported by (Smallfield 2001).Rosemary (Rosemarinuse officinialis L.) is an aromatic, medicinal and condiment plant that belongs to the family labiatae, reaching a height of 1.5 meters. Essential oil of rosemary, known as rosemary oil, is obtained by steam distillation method of the fresh leaves and twigs. The yield ranges from 0.5 to $1.5 \%$ (w/w) (Mateus et al 2006). Chemical composition and physicochemical characteristics have been reported for rosemary essential oil. It is an almost colorless to pale yellow liquid with a characteristic, refreshing and pleasant odor. Major components characterized for the oil are $\alpha$-pinene, 1,8-cineole and camphor (Boutekedjire et al. 2003). The effect of extraction time on the yield and composition of rosemary oil has been reported in two different methods; steam distillation and hydrodistillation (Masango 2005). The composition of oil may vary to a large extent depending on the extraction method used. Steam distillation process was modeled as an inevitable step to project industrial plants with good operational condition (Cassel et al. 2009 and Bimakr et al., 2011). showed that conventional soxhlet extraction of flavonoids of spearmint took $6 \mathrm{hr}$ for $3 \mathrm{~g}$ of dried and ground plant at $40^{\circ} \mathrm{C}$ using solvents such as ethanol, methanol. So, they proposed supercritical extraction with $\mathrm{CO} 2$ to obtain high efficiency (Bimakr et al 2011). Therefore, solvent extraction does not perform well. In the present study, a column was designed and constructed in order to evaluate the steam distillation process for the extraction of rosemary oil. Optimal operating 
conditions were determined in order to achieve high extraction yields. Also, it can be analyzed the effect of different parameters on chemical composition of the extracted rosemary oil. The novelty of the process is introducing multistage beds of plant in order to achieve a better extraction of target materials through enhancing mass transfer operation.

\section{MATERIAL AND METHOD}

\section{1- Plant material}

The rosemary samples were collected obtained from the farm of the Medicinal and Aromatic Plants Research Department, Dokki, Giza, in 2018. Fresh plant materials were carefully separated into leaves and stems. The samples were dried in the shade for 5 days for use in the research experiments and the primary moisture of the leaves was $60.2 \%$ (w.b). For the extraction of essential oils, 100 grams of each powder sample was used and then the essential oils isolated by hydro distillation and steam distillation are isolated for 5, 15, 30, 60 and 120 minutes. Then separating essential oils from the water layer and drying them over anhydrous sodium sulphate, and calculating the average yield of aromatic oil.

\section{2- Essential oil extraction}

Essential oil was extracted from each of the plant parts by two extraction methods:

\subsection{1- hydro distillation}

The Clevenger-type apparatus hydro distillation was used for this purpose for is shown in Fig. (1). A mixture of Rosemary leaves or powder (200 g) and $1000 \mathrm{ml}$ of water was put into a $2000 \mathrm{ml}$ round bottomed flask. The temperature was set at $80 \mathrm{C}$ for the extraction of essential oil. The process in Clevenger-type apparatus was run for the time till no further oil could be extracted. The essential oil was vaporized with the steam. Condensation occurred as the vapours of essential oil and steam mixture passed through a condenser. The condensate, a mixture of oil and water, was then separated. Essential oil being lighter settled above water and it was collected. To study the kinetics of extraction of oil, essential oil was collected at regular intervals during the extraction process. 


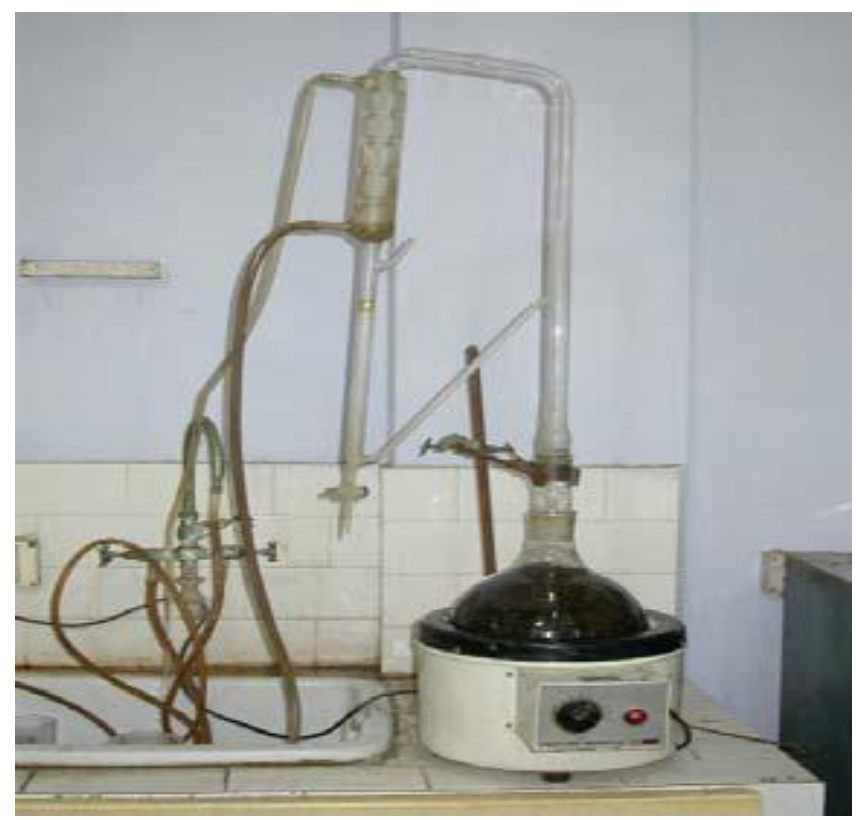

Fig. (1 ). Essential Oil hydrodistillation

\subsection{2- Steam distillation apparatus and procedure}

A schematic diagram of the steam distillation apparatus used for essential oil extraction is shown in Fig. (2). The apparatus has a cylindrical Pyrex body (6 cm inside diameter and $60 \mathrm{~cm}$ height). A batch of 100-200 g of dried and ground leaves of rosemary was packed in the column with 2000 $\mathrm{ml}$ water in steam source. The raw material forms the packed bed. The lid was closed and the process of distillation began with the injection of steam to the bottom of the column. Each plant bed was exposed to several flow rates of steam. Steam and essential oil were condensed and collected in time intervals of 5, 15, 30, 60 and 100 minutes. Following condensation, the mixture was decanted to separate phases of oil and water. The essential oil was collected, dried with anhydrous sodium sulfate and stored at $4^{\circ} \mathrm{C}$ until analyzed. In these experiments, the steam jacket of the column was insulated by foam cover having $1 \mathrm{~cm}$ thickness. After doing the experiments and determining the yield of each experiment, the obtained samples from the three experiments with steam flow rates of 3,6 and 9 $1 / \mathrm{min}$ and a packed bed of $100 \mathrm{~g}$ that were collected at five intervals, namely 5, 15, 30, 60 and 100 minutes, were analyzed by GC-MS and GC 
instruments. Each experiment was repeated at least three times and mean of results was reported.

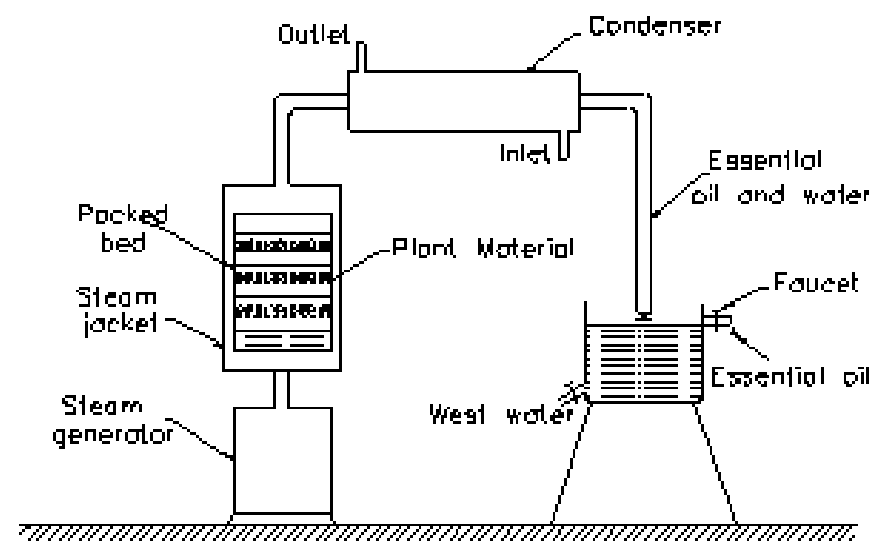

Figure 2. Schematic diagram of the steam distillation apparatus.

\section{3 -Volatile oils:}

The essential oil yield was estimated according to the dry vegetal matter by using the following equation:

$$
\mathrm{Y}=\frac{\text { Moil }}{\mathrm{s} \mathrm{M}} \times 100
$$

Where: Y: Percentage of Essential oil yield [w/w].

$M_{\text {oil }}$ : Mass of essential oil [g].

Ms: Mass of dry plant [g].

The percentage of volatile oil of different plants was measured at the end of drying process and calculated as follows:-

Volatile oils $\%=\frac{\text { volum of distillation vlatile oils }}{\text { weight of leaves sample }} \times 100 \ldots$ (2)

\section{4 - Gas chromatography-mass spectrometry identification}

GC analyses were carried out using a Hewlett-Packard 6890 with HP-5 capillary column (phenyl methyl siloxane, $25 \mathrm{~m} \times 0.25 \mathrm{~mm}, 0.25 \mu \mathrm{m}$ film thickness) and a DB-1 capillary column $(30 \mathrm{~m} \times 0.25 \mathrm{~mm}, 0.25 \mu \mathrm{m}$ film thickness). The temperature of oven was programmed to $60-240^{\circ} \mathrm{C}$ at $4^{\circ} \mathrm{C} / \mathrm{min}$; injector temperature, $250^{\circ} \mathrm{C}$; detector temperature, $260{ }^{\circ} \mathrm{C}$; carrier gas, He $(1.5 \mathrm{ml} / \mathrm{min})$; split ratio, 1:25. GC-MS analyses were carried out applying a Hewlett-Packard 6859 with a quadropol detector, on 
a HP-5 column (see GC), operating at $70 \mathrm{eV}$ ionization energy, using the same temperature programmer and carrier gas as above.

\section{RESULTS AND DISCUSSION}

The results obtained from the extraction of essential oil from the rosemary plant in two methods of extraction as follows:

\section{1- hydro distillation}

The yield of the hydrodistillation was $0.44 \%$. The essential oil yield as a function of time is shown in Fig. 3, and all oils are recovered after $30 \mathrm{~min}$. In addition, the yield increases quickly at the beginning of the extraction, its evolution becoming slower thereafter. whereas for the hydrodistillation it takes at least $30 \mathrm{~min}$ to extract $88 \%$ of the oil. Analysis by gas chromatography of the oil recovered with regular time intervals enabled us to follow the evolution by time of the relative content of some major components of oil belonging to various known chem- ical families: 1,8-cineol, camphor, borneol, $\alpha$ terpineol, bornyl acetate, $\beta$-caryophyllene and $\delta$-cadinene,as shown in Fig.4. Also Fig.4 shows a rapid evolution of the content of the considered components, and those recovered in the ascending order of their boiling points. then the $\beta$-caryophyllene follows them with a maximumcontent after $15 \mathrm{~min}$ The fact that the components considered are recovered in the ascending order of their boiling points The 1,8-cineol and camphor are recovered in greater proportion after $10 \mathrm{~min}$ hydrodistillation, as shown in Fig. 3. it can be observe thereafter the simultaneous extraction of borneol, $\alpha$-terpineol, bornyl acetate and $\beta$-caryophyllene, which reach their optimal contents after $20 \mathrm{~min}$ of the process. After $30 \mathrm{~min}$, only traces of these components are recovered. In addition, the considered components are not recovered in the order of their boiling points. Indeed, 1,8-cineol is collected at the same time ascamphor, whereas it is more volatile. The same happensfor other components which have different boiling points.

\section{2 - Steam distillation}

The isolation and concentration of essential oils were performed in single stage and multistage column with three steam flow rates. The yield was 
calculated from the relation between the mass of obtained oil and the mass of raw material used in the experiments.

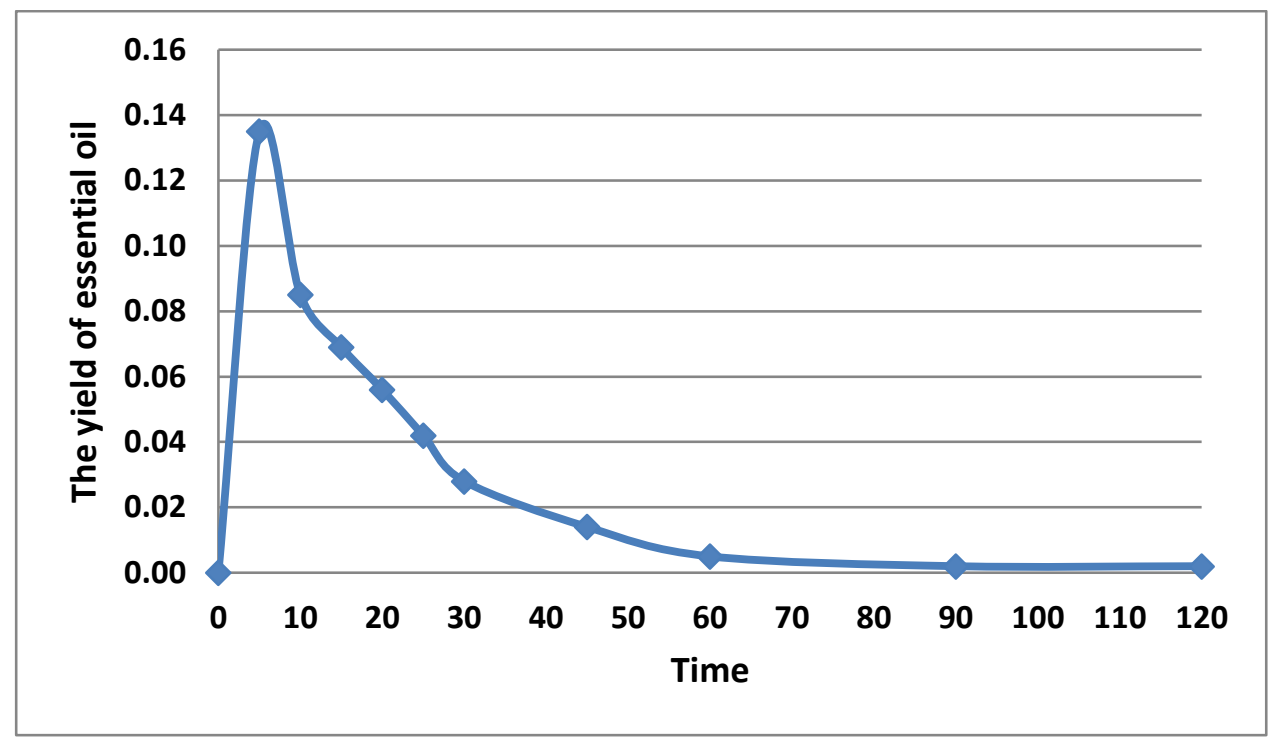

Fig.(3) Evolution of essential oil yield as related to extration time.

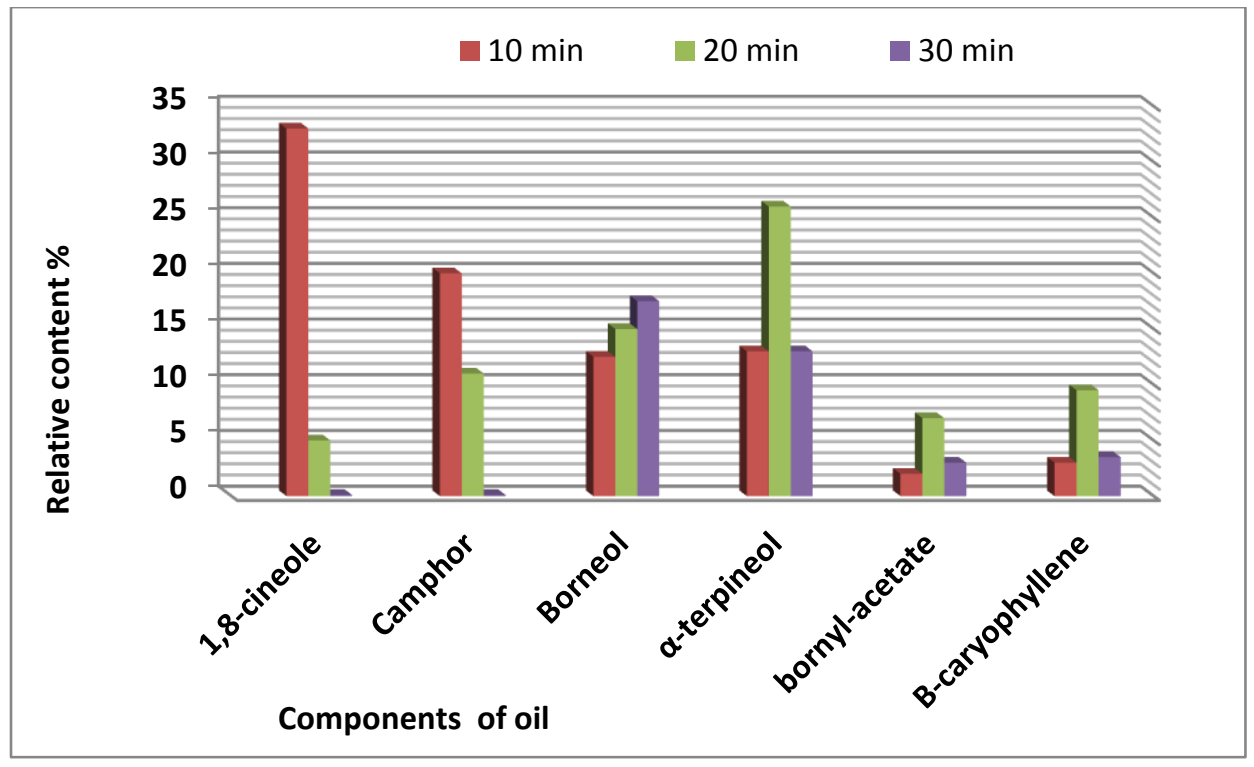

Fig.(4) Evolution of the content of some conponents of rosemary essential oils during hydrodistillation process 
The three different steam flow rates (3, 6 and $91 / \mathrm{min})$ and a packed bed of $100 \mathrm{~g}$ were used. The results are shown in Fig. 5. It can be seen from this figure that as steam flow rate decreases, the amount of oil increases monotonically in each of the five intervals. The greatest yield was obtained for the steam flow rate of $31 / \mathrm{min}$, which was 1.074 . Also, from the sharpness of the slope during the first 30 minutes, it can be observed that the highest extraction rate occurs in the first 30 minutes of extraction time. In general, in most cases of the experiments, between 85 and 95 percent of total oil was extracted during this interval. The effect of height of packed bed on the extraction yield of essential oil was considered for two steam flow rates of 3 and $6 \mathrm{l} / \mathrm{min}$ and packed beds with the heights of 30,45 and $60 \mathrm{~cm}$. These heights were equal to 100, 150 and $200 \mathrm{~g}$ of plant, respectively.

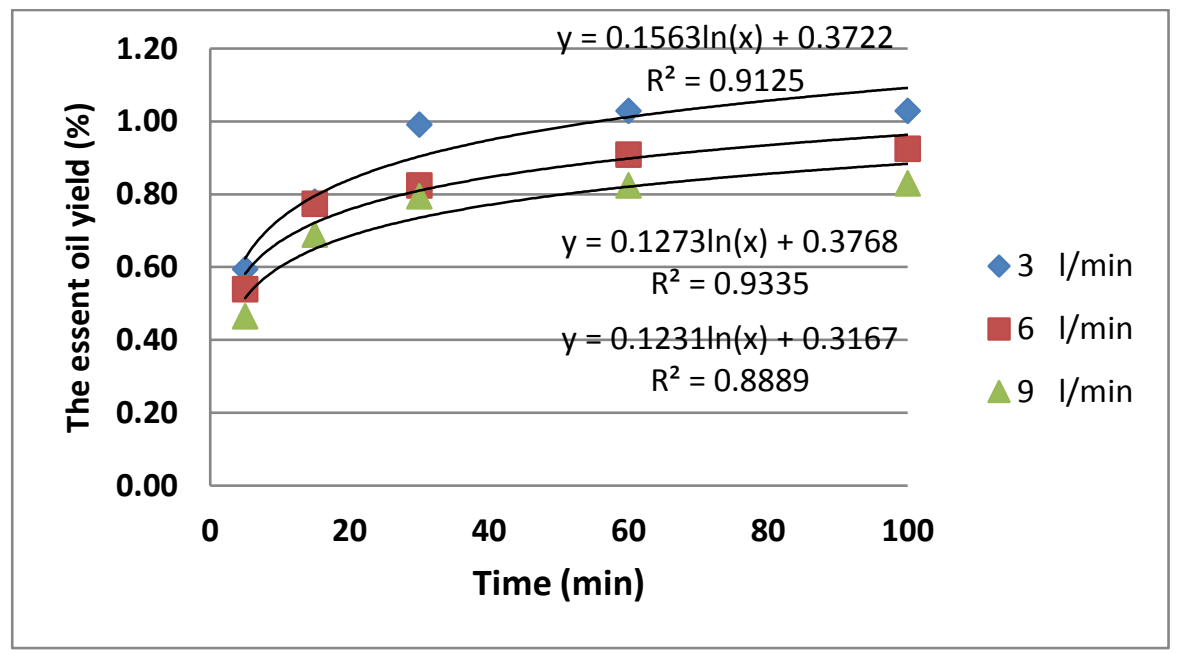

Fig.(5) Extraction yield as a function of processing time under different steam flow rates.

The results of these experiments are presented in Figs. 6 and 7. It was evident from these experiments that with an increase in the mass of the packed bed, a sharp decrease occurred for the total yield of the extraction, depending on the steam flow rate. Furthermore, the slope of the curves for the packed beds of 45 and $60 \mathrm{~cm}$ of height were less during the 30 minutes in comparison with that of $30 \mathrm{~cm}$ height of bed. It revealed that the 
amount of extraction was less in this interval for higher heights of single packed bedAn increase in the height of the packed bed caused higher pressure drop. As a result, the total yield of the extraction decreased. To avoid this problem, steam redistributors were used between every two successive beds of the column.

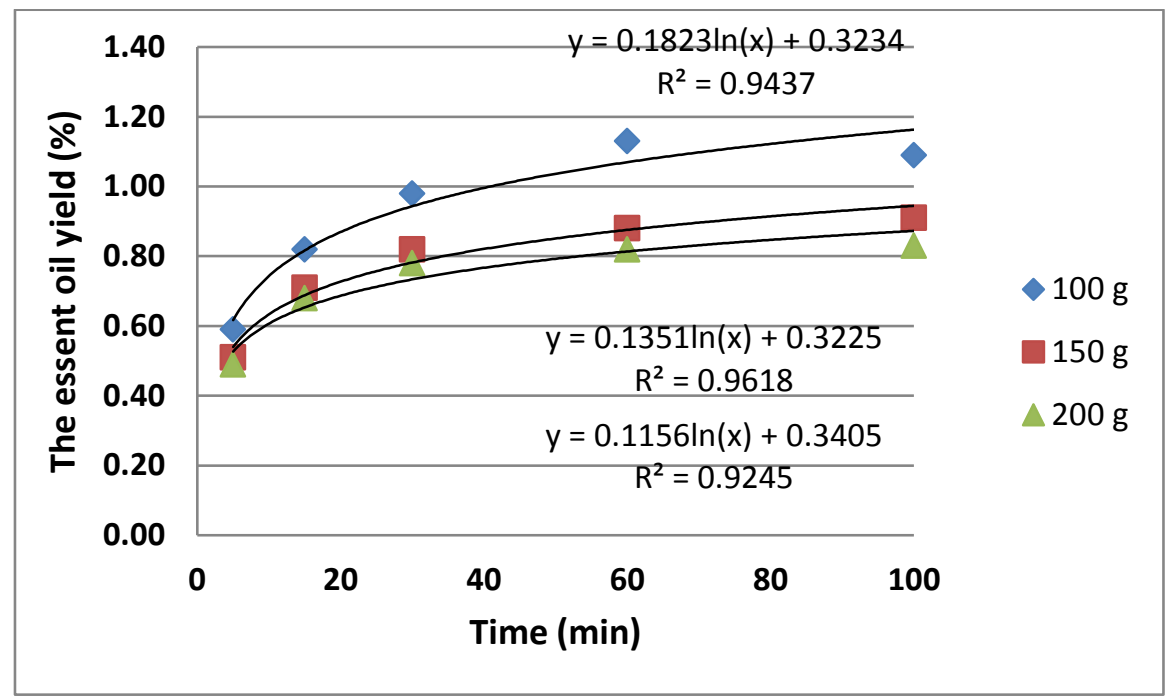

Fig.(6).Yield curves of rosemary oil samples for different masses of packed beds for steam flow rate of $3 \mathrm{l} / \mathrm{min}$.

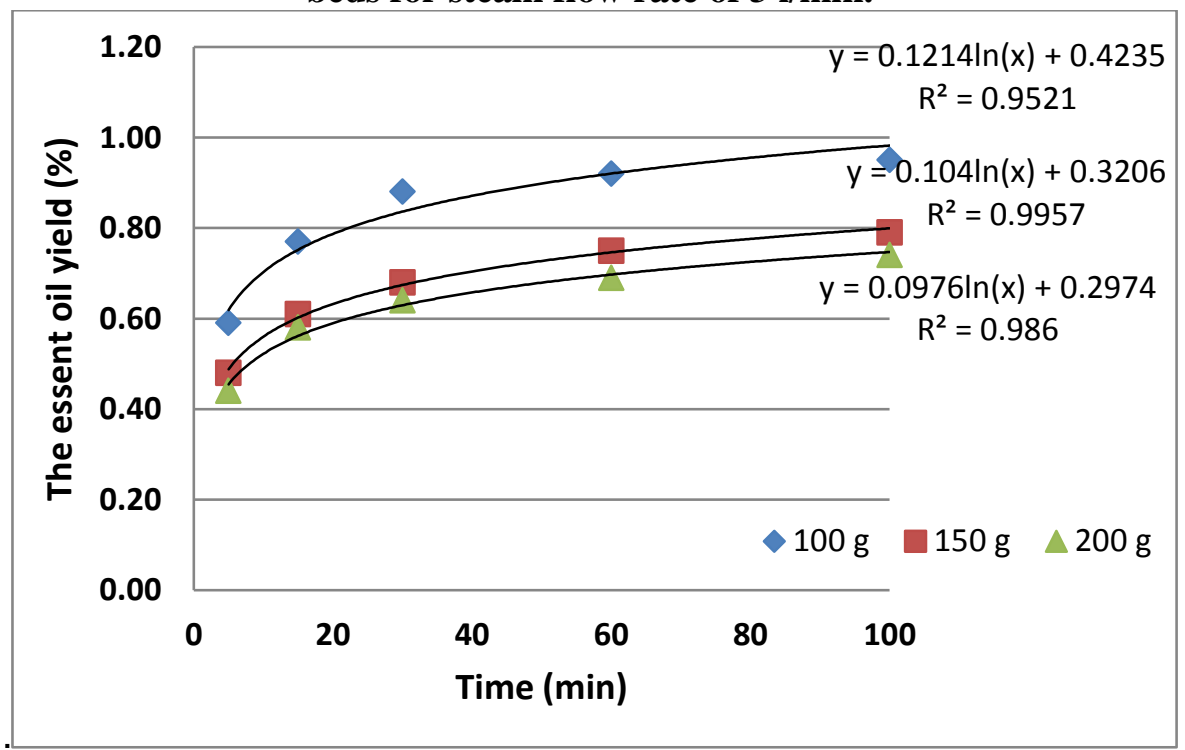

Fig.(7). Yield curves of rosemary oil samples for different masses of packed bed for steam flow rate of $6 \mathrm{l} / \mathrm{min}$. 
As seen in Figs. 5 to 7, using two or three stages of beds caused an increase in the total yield of the extraction, and the yield of such process in onestage column with a mass of $150 \mathrm{~g}$ and a steam flow rate of $6 \mathrm{l} / \mathrm{min}$ reached from 0.776 to $1.03 \%$ in a three stage column with the same condition Fig. (8). As shown in Fig. (9). Reduction of total mass of beds at the same steam flow rate of the previous condition enhanced the yield. With respect to Fig. 10, a decrease in the steam flow rate and also a decrease in the mass of the packed plant with the same height of column caused a yield increment up to $1.36 \%$. However, using more stages does not cause any increase in the total yield. With a decrease in the height of the packed bed, a decrease in the steam channeling was observed. But, here the contact between steam and the internal walls of the column increased, which in turn caused the steam condensation on the internal walls of the distillation column which returned to the packed bed The results of GC-MS analysis showed that rosemary oil has 61 components with the concentration between 0.01 and 15.47 percent.

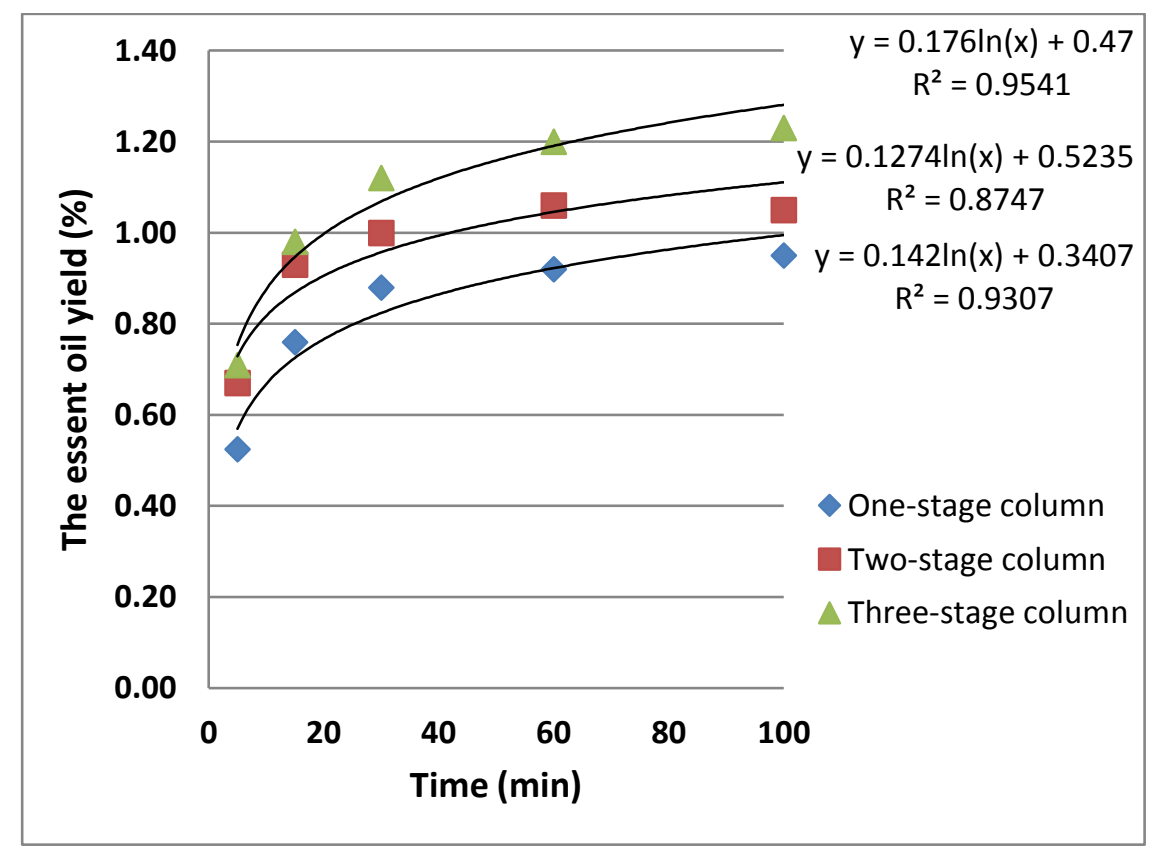

Fig.(8). Yield curves of rosemary oil samples for multistage column with steam flow rate $6 \mathrm{l} / \mathrm{min}$ and packed bed of $150 \mathrm{~g}$. 


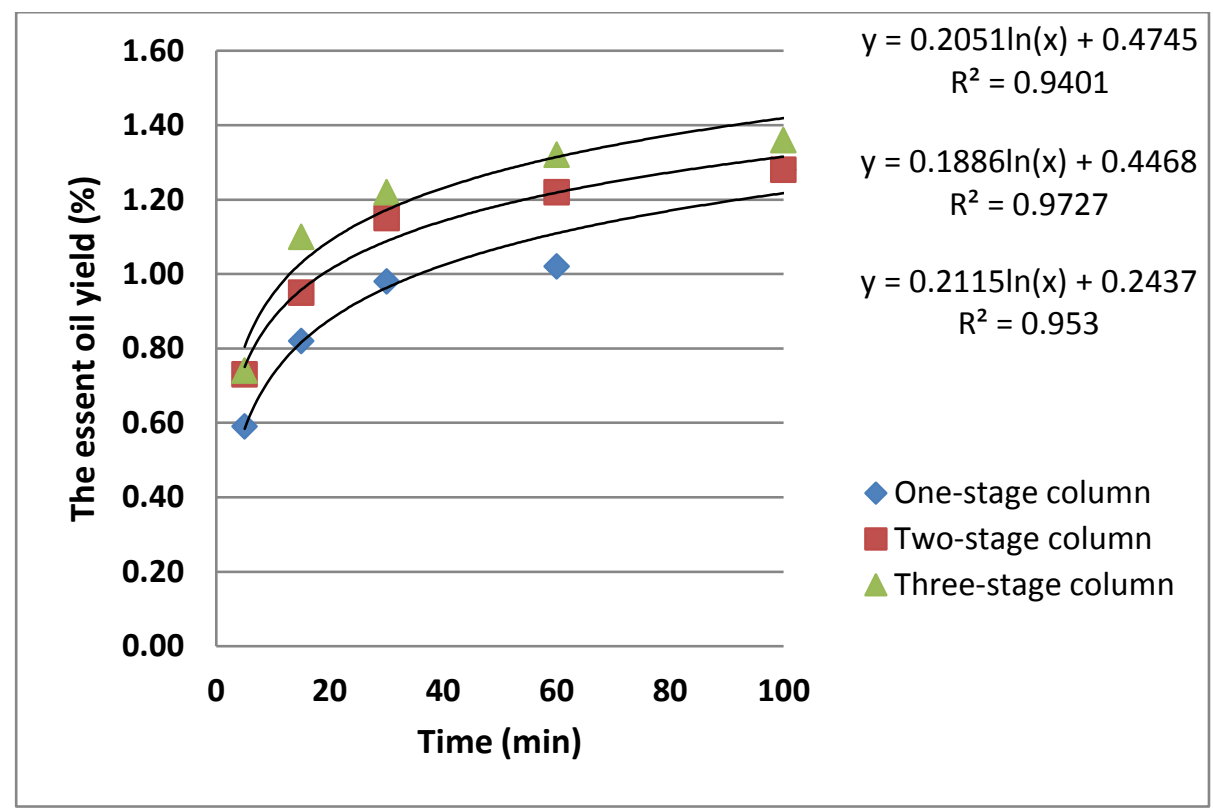

Fig.(9). Yield curves of rosemary oil samples for multistage column with steam flow rate $6 \mathrm{l} / \mathrm{min}$ and packed bed of $100 \mathrm{~g}$.

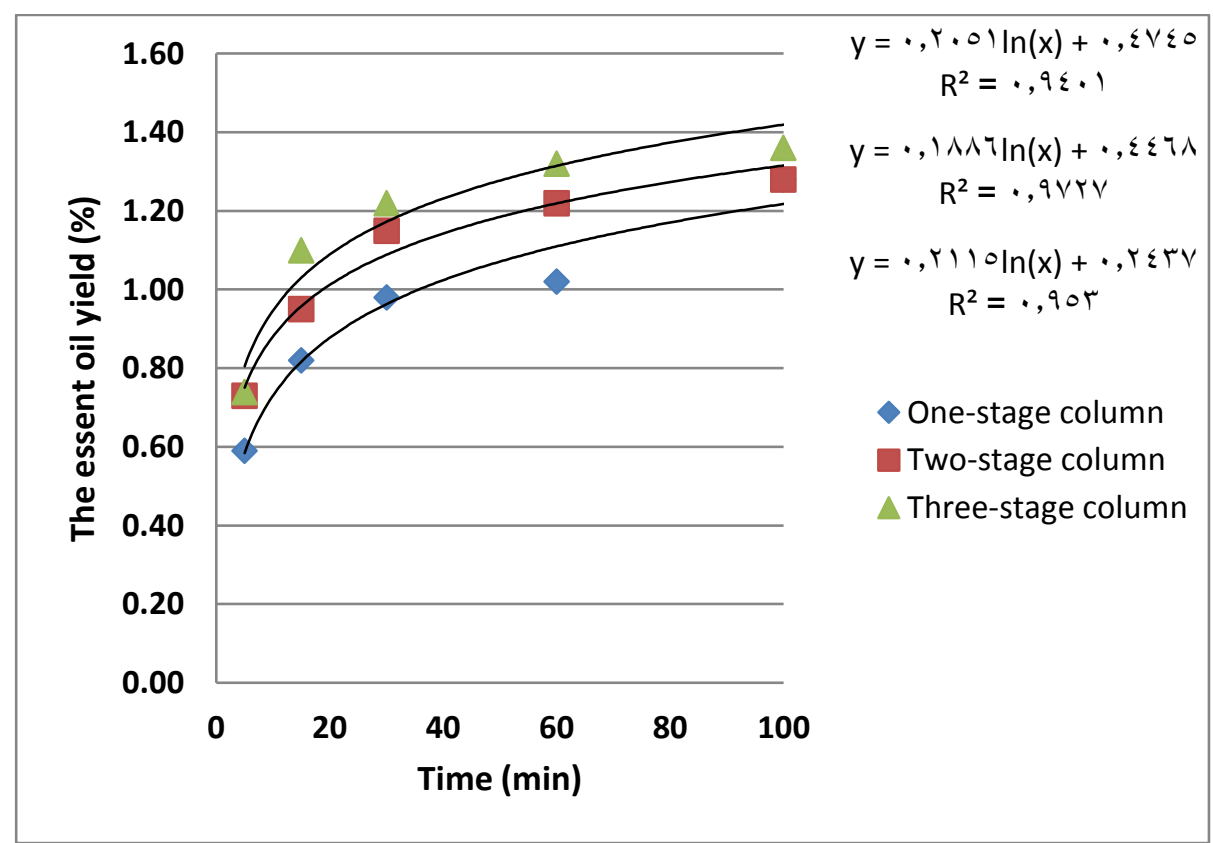

Fig. (10). Yield curves of rosemary oil samples for multistage column with steam flow rate $3 \mathrm{l} / \mathrm{min}$ and packed bed of $100 \mathrm{~g}$. 
The results of gas chromatography were analyzed for three experiments with steam flow rates of 3,6 and $91 / \mathrm{min}$ and a packed bed with a mass of $100 \mathrm{~g}$. The three most important components ( $\alpha$-pinene, 1,8-cineole, and camphor) were selected and changes in their concentration in relation to the time of extraction were studied during 5, 15, 30, 60 and $100 \mathrm{~min}$ intervals (Figs. 11 to 13). For $\alpha$-pinene a maximum extraction occurred in the first 5 minutes, following a decrease during 15 minutes and an increase in the further 30 minutes of extraction was observed. For 1,8-cineole, decrease in extraction amount occurred during the time of extraction. Low extraction was observed for camphor in the first 5 minutes; a maximum extraction occurred at 15 minutes and was followed by decreasing with time. Varying steam flow rate had no effect on the behavior of each component.

Generally, Experiments showed variations in the amount of components with time. The results indicated weak effect of steam flow rate on the essential oil components. In other words, a change in the amount of steam flow rate does not lead to either increase or decrease in any considerable components of Rosemary essential oil. However, the time of distillation has an effect on the constituents of essential oil. This effect was studied for three important components of Rosemary essential oil: $\alpha$-pinene, 1,8cineole, and camphor. Each of these components showed different behavior in contact with steam flow rate during time intervals. First, barrier effect, and second, the boiling points of components. In the case of $\alpha$-pinene, barrier effect is active and for camphor and 1,8-cineole, the boiling point is effective.

It should be noted that some of the $\alpha$-pinene is present in the cell of plant walls and some exists inside these cells. This increase and decrease is due to evaporation of compounds that exist between these cells. Another reason is the time needed to destroy the cell walls that contain essential oils. But in the case of camphor and 1,8-cineole, this trend is the result of their boiling points. 1,8-cineole has the boiling point of $176 \mathrm{C}$, and camphor has the boiling point of $209^{\circ} \mathrm{C}$. Each of these components showed different phenomenon in contact with steam flow rate during time intervals. 


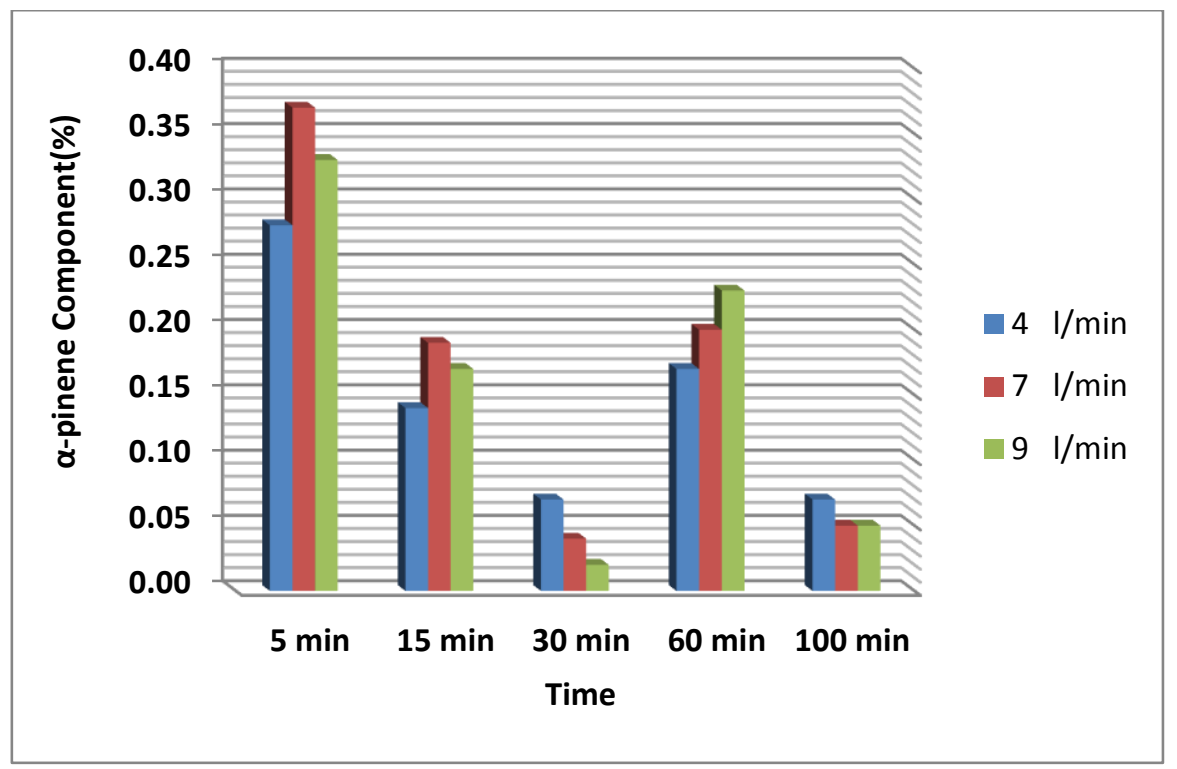

Fig.(11).Change of alpha-pinene concentration in terms of time for different steam flow rates.

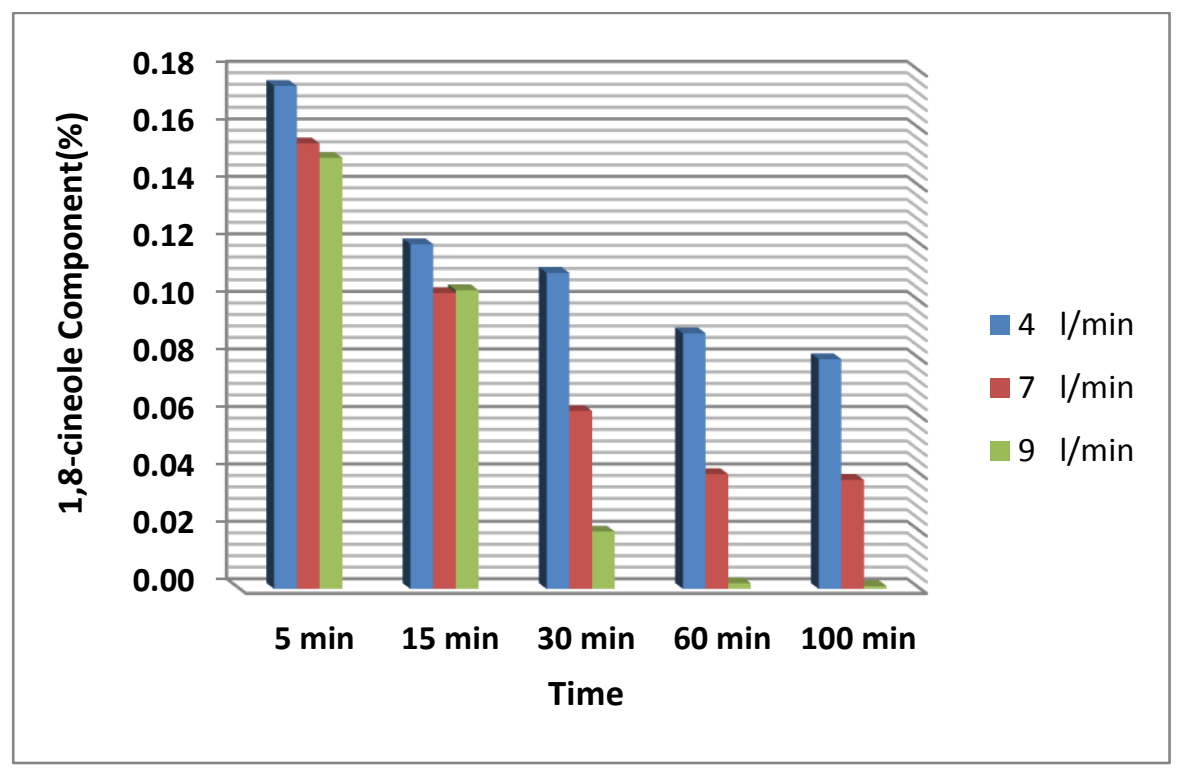

Fig.(12).Change of 1,8-cineole concentration in terms of time for different steam flow rates. 


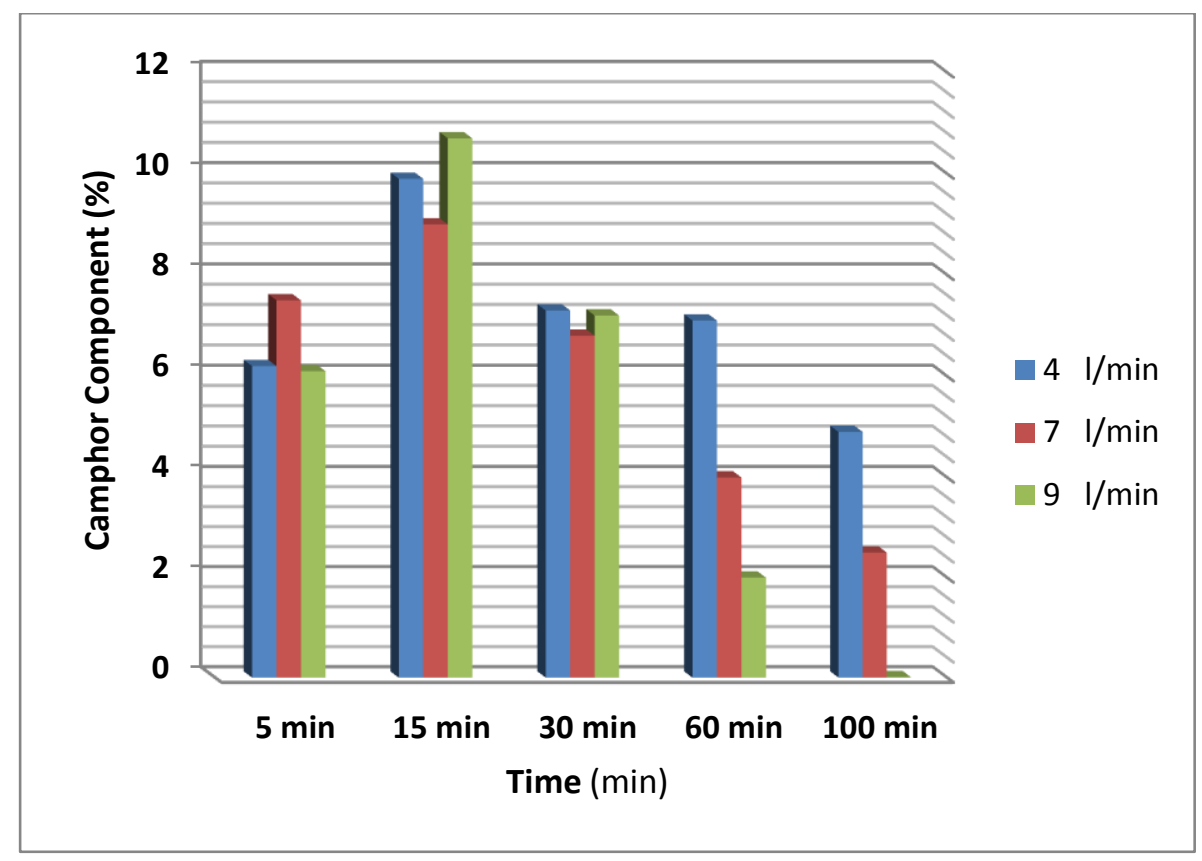

Fig.(13).Change of camphor concentration in terms of time for different steam flow rates.

\section{REFERENCES}

Bimakr, M., R.A. Rahman, F. S. Saleena, A. Ganjloo, L. Md Salleh, J. Selamat, A. Hamid and I. S. M. Zaidul (2011). "Comparison of different extraction methods for the extraction of major bioactive flavnoid compounds from spearmint (Mentha Spicata L.) leaves", Food and Bioproduct Processing, 89, 67.

Boutekedjiret, C., F. Bentahar, R. Belabbes and J. Bessiere (2003). "Extraction of rosemary essential oil by steam distillation and hydrodistil-lation", Flavour and Fragrance J., 18, 481.

Cassel, E., R. M. E. Vargas, L. Martinez, N. D. and E. Dellacassa (2009) "Steam distillation modeling for essential oil extraction process", Industrial Crops and Products, 29, 171.

Chemat, F., M. Lucchesi, J. Smadja, L. Favretto, G. Colnaghi and F. Visinoni (2006). " Microwave accelerated steam distillation of 
essential oil from lavender: A rapid, clean and environmentally friendly approach", Analytica Chimica Acta, 555, 157.

\section{Rajeswara, R., B. R. Kaul, P. N. Syamasundal, K. V. and S. Ramash} (2002). "Water soluble fractions of rose-scented geranium (pelargonium species) essential oil", Bioresource Technology, 84,243 .

Romdhane, M. and C. Tizaoui (2005). "The kinetic modelling of a steam distillation unit for the extraction of aniseed (pimpinella anisum) essential oil", J. Chem. Technol. Biotechnol., 80,759.

Mateus, E. M., C. Lopes, T. Nogueira, J. A. A. Lourenco and M. Curto, R. Rajeswara, B. R. Kaul, P. N. Syamasundal, K. V. and S.Ramash (2006). "Water soluble fractions of rose-scented geranium (pelargonium species) essential oil", Bioresource Technology, 84,243.

Masango, P. (2005). "Cleaner production of essential oils by steam distillation", J. Cleaner Production, 13, 833.

Smallfield, B. M., J. W. Van Klink, N. B. Perry and K. G. Dodds (2001) ."Coriander spice oil: Effects of fruit crushing and distillation time on yield and composition", J. Agric. Food Chem., 49, 118.

الملخص العربي

استخر اج زيت نبات حصالبان بواسطة التقطير بالبخار والتقطير المائي

د/ جمال كمال عرفهة

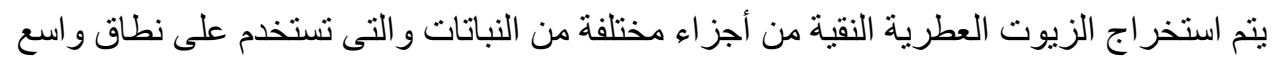

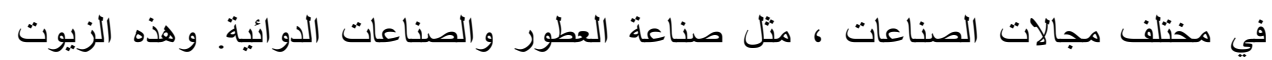

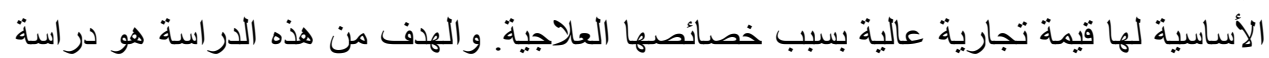

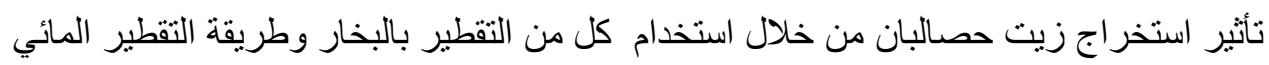
على كميتة ومكوناتة ونسب تحليل الزيت المقطر و تحليل الزيت كروماتوجر افيا الغاز * باحث أولـ معهد بحوت الهندسة الزراعية ـ مركز البحوث الزراعيةـ مصر 


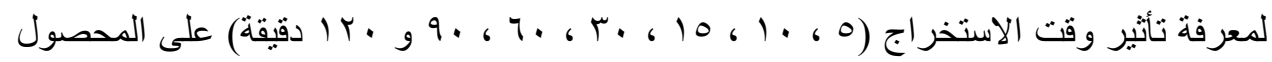

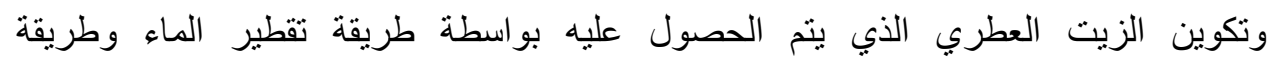

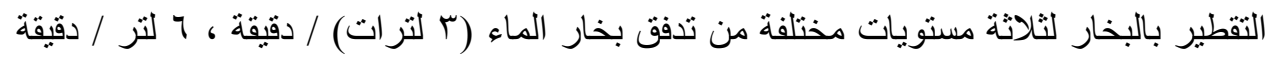

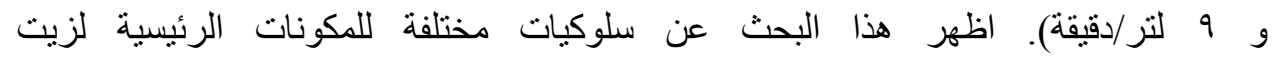
حصالبان camphor a-pinene ف في المعالجة مع مقدار معدل تدفق البخار. أظهرت التجربة أن طريقة تقطير البخار أفضل من طريقة تقطير الماء بناءً على نسبة الزيت البخات وكميته وكذلك مكوناته. 